\title{
The Role of In Spiritual Education
}

\author{
Kamolatdin Ismoilov, Tashkent Pharmaceutical Institute, Tashkent, Republic of Uzbekistan \\ Pulat Abdukodirov, Tashkent Pharmaceutical Institute, Tashkent, Republic of Uzbekistan \\ Saodat Yuldasheva, Tashkent Pharmaceutical Institute, Tashkent, Republic of Uzbekistan \\ Mohira Allanazarova, Tashkent Pharmaceutical Institute, Tashkent, Republic of Uzbekistan \\ E-mail: ifk_tashfarmi@mail.ru
}

\begin{abstract}
In today's globalized world, in the context of the ongoing spiritual and ideological struggle between Eastern and Western civilizations, the problem of preserving the nation and preserving national sovereignty by achieving national development has become more urgent than ever. Not only in the East, but also in the West itself, progressive intellectuals are concerned about this. The same conceptual idea is expressed in the program idea "From national revival to national progress" put forward by the President Sh.M.Mirziyoev.
\end{abstract}

Keywords: Spirituality, Enlightenment against Ignorance, Youth, From National Revival to National Rise, Civil Society.

Received: 07.12.2020 $\quad$ Accepted: 13.01.2021 $\quad$ Published: 06.02.2021

\section{INTRODUCTION}

In this regard, the large-scale reforms being carried out under the leadership of President Islam Karimov, in particular, the emphasis on the scientific organization of state and public administration, the development of civil society, the radical renewal of all levels of education on the basis of modern standards. . In particular, the Decree of the President of the Republic of Uzbekistan dated April 8, 2019 "On measures to develop the concept of development of the national idea at a new stage of development of Uzbekistan", adopted on May 3, 2019 "Additional measures to increase the effectiveness of spiritual and educational work." Resolution No. PQ-4307 of the Constitution of the Republic of Uzbekistan urges us to live with a sense of responsibility to serve the path of national democratic development, while inspiring us.

"As we decide to build a new Uzbekistan, we will rely on two strong pillars. The first is a strong economy based on market principles. The second is the rich heritage of our ancestors and a strong spirituality based on national values.11

The great creative work carried out in independent Uzbekistan, the conditions created for the development of the individual encourage him to realize his identity and to mobilize his talent, mind and consciousness to work selflessly for the development of the people and the Motherland.

There is no doubt that the 21st century will be a time of great change. These changes are inevitable, first and foremost, in the way a person thinks. In turn, the first President of Uzbekistan IA Karimov said, "Raising our dear children not only physically and spiritually healthy, but also making them a harmoniously developed generation with the most modern intellectual knowledge and wealth that we live in the XXI century. ensuring that they enter life as human beings ... "is one of the most important factors. 4

In this regard, the first President of Uzbekistan IA Karimov, in his book "High spirituality - an invincible force" thinks about the formation of personal spirituality, the deeper the sense of love for the motherland, the deeper the roots of love for the motherland. , emphasizes the need to create a spiritual environment for this, emphasizing that the love for the country of birth and upbringing is so high, and that a person who is rooted in national pride and patriotism is capable of great deeds4.

We rightly call the 21st century we live in a time of miracles. Indeed, incredible changes are taking place today. Life itself promotes teaching young people to approach the growing flow of scientific and political information to increase their knowledge independently. An important task of this day is to develop skills and abilities aimed at developing the thinking of young people, improving their ability to work independently. Achieving our goals depends on building a new democratic society, what intellectual forces we have, what cultural and professional level our youth has reached, what ideas they believe in, how spiritually rich they are. It is necessary to pay special attention to the humanization, tolerance, scientific and spiritual ratio of the activities of modern educational institutions in the field of social sciences and humanities, because the 
orientation of the younger generation is one of the most pressing issues today. Defining and carefully planning the content of group educational hours, ie topics according to the seasons, holidays, historical dates and events, peace, friendship, labor, family, happiness, career choice, love of nature, patriotism, ancestral heritage, national and universal values shows that classification is the key to great success. After gaining its independence, the task of educating a free-thinking, self-aware, understanding of the goals and interests of society, a fully developed person has been identified as a priority of state policy. Its implementation, first of all, requires the enrichment of the inner spirituality of the pupils and the formation of an independent worldview. In his speech at the opening ceremony of the Public Library under the President of the Republic of Turkey in Ankara on February 20, 2020, President of the Republic of Uzbekistan Shavkat Mirziyoyev said, "Every country, every nation in the world is strong, first of all, with its intellectual potential and high spirituality. Such an invincible source of power is, first of all, a great discovery of human thinking - in books and libraries, "said the President.

Spirituality is a multifaceted concept. It encompasses all aspects of human activity, including its apparent and hidden, inner spiritual aspects. It is difficult to find a clear and concise answer to the question of what spirituality is. He was told various, and sometimes contradictory, vaguely shallow answers and opinions.

The concept of "spirituality" and its principles are given specific interpretations and definitions. This is due to the fact that the concept of "spirituality" in the broadest sense is a socio-spiritual phenomenon that fully embodies the ideological, ideological, enlightenment, cultural, religious and moral views of society.

In fact, spirituality is the most powerful spiritual factor that separates man from all other beings. When we say that man is the flower of nature, the flower of all beings, we mean his ability to have this quality, that is, high spirituality. We do not see this possibility in other creatures.While material things give a person physical nourishment and strength, spirituality gives him spiritual nourishment and strength. Self-sufficiency in material possessions is characteristic of unconscious and soulless creatures. The pursuit of spirituality, on the other hand, is a characteristic of human beings who possess spirit and consciousness. Spirituality is a complex social phenomenon as a set of human mental and spiritual worlds.

Thus, spirituality is the ability to set a person's psyche, his self-awareness, taste, intellect, justice and consent, good and evil, beauty and ugliness, calmness and ignorance, intelligence, lofty goals and ideas, and their implementation. is the potential to act and strive for - we think it is appropriate to describe. Of course, we cannot say that this definition is perfect. After all, "spirituality is not a gift of destiny. For spirituality to be perfected in the human heart, it must work with the heart and conscience, the mind and the hand." Spirituality is formed at the birth of a person in layers with mother's milk, his goddess, kindness, ancestral teachings, sense of homeland, sometimes bitter, sometimes joyful lessons of this life. The family environment, social cohesion, justice and humanism in the policy pursued by the state play a key role in its decisionmaking.The role and influence of the family in the formation and development of the unique spirituality of each nation is incomparable. Because the purest and purest feelings of a person, the first life concepts and imaginations are formed first of all in the heart of the family. The spiritual criteria and attitudes that determine the character, nature and worldview of a child entering life - the foundation of sacred concepts such as goodness and kindness, nobility and kindness, honor and dignity - are valued in the family setting.

The dangers to the spiritual world today cannot be ignored, but we are convinced that our people have been strengthened in the complex processes of history, that the spiritual world is growing stronger and stronger in spite of all attacks and oppressions, and that even the forces that cannot see us recognize this fact. note with.

"Today, most of our children are brought up not by school, parents or institutes, but by the phone in their hands. The mobile phone is no longer just a means of communication, it is often becoming a weapon to spread foreign ideology.

Harmful ideas, which are completely alien to our spirituality, are entering our homes and society without violating the borders. It's coming in by the minute, not by the hour.

All this should sound like a wake-up call for us, "Mirziyoyev said.At the same time, our deep-rooted national qualities, such as our centuries-old mental qualities, tolerance and intelligence, care for the Motherland and striving for its prosperity, are evolving. We believe that the shallowness of the mind among our youth, the growing dogmatic worldview, the growing religious factor, the preference to work in foreign countries and organizations rather than in the interests of their homeland, the alienation from national identity. In this sense, on the basis of the idea of "Enlightenment against ignorance" repeatedly emphasized by President Sh.M. today it is more necessary than ever. 4 In conclusion, it should be noted that the meaning of spirituality, its place and importance in human and social life, the theoretical and practical aspects of this complex and multifaceted concept have been analyzed through a wide range of ideas and conclusions. At the same time, 
during the years of independence, the great work being done in our country to restore our national spirituality, to develop it on the basis of modern requirements, the goals and tasks ahead of us in this regard have been discussed in detail. In today's complex globalization, special attention is paid to the current problems in the field of spirituality, the preservation and promotion of the spirituality of our people, especially the protection of the hearts and minds of the younger generation from various harmful ideas and ideologies.

\section{References}

1. 1.Mirziyoev Sh.M. We will build our great future together with our brave and noble people. - Tashkent: "Uzbekistan", 2017.-491 p.

2. Address of the President of the Republic of Uzbekistan Shavkat Mirziyoyev to the Oliy Majlis. // January $24,2020$.

3. Speech by President Shavkat Mirziyoyev at the solemn ceremony dedicated to the twenty-seventh anniversary of state independence of the Republic of Uzbekistan // August 31, 2020.

4. 4.Karimov I.A. High spirituality is an invincible force.T .; "Spirituality". $2008 \mathrm{y}$.

5. National idea: Texts of lectures on the strategy of development of Uzbekistan.-Gulistan: 2018.

6. Decree "On measures to develop the concept of development of the national idea at a new stage of development of Uzbekistan", April 8, 2019

7. Resolution No. PQ-4307 "On additional measures to increase the effectiveness of spiritual and educational work", May 3, 2019

8. Speech of the President of the Republic of Uzbekistan Shavkat Mirziyoyev at the opening ceremony of the Public Library under the President of the Republic of Turkey in Ankara on February 20, 2020.// February 20,2020

9. Address of the President of the Republic of Uzbekistan Shavkat Mirziyoyev to the Oliy Majlis. // December 29, 2020

10. Speech of the President of the Republic of Uzbekistan Shavkat Mirziyoyev at the Youth Forum of Uzbekistan.// December 26, 2020

11. Video conference on radical improvement of the system of spiritual and educational work, strengthening cooperation between government and public organizations in this regard.//January 19, 2020' 